\title{
A histology-based study in apparently healthy wild freshwater stingrays Potamotrygon motoro
}

\author{
Julieta Engrácia de Moraes ${ }^{1,2}$ • Jefferson Yunis Aguinaga ${ }^{2}$. \\ Pedro de Oliveira Viadanna ${ }^{2}$. Flávio Ruas de Moraes ${ }^{1}$
}

Received: 21 May 2015 / Accepted: 8 July 2015 / Published online: 6 August 2015

(C) Springer-Verlag London 2015

\begin{abstract}
Histopathological studies are important as a reference in pathological process. There are a few of these studies in elasmobranchs. The aim of this study was to describe the histology of kidney, spleen, liver, and gills of wild apparently healthy Potamotrygon motoro. However, we observed some pathological findings in these animals. Nineteen P. motoro were collected from the Parana River, Brazil. Histology of kidney, spleen, liver, and gills were performed according to usual procedures. Briefly, the organs were immersed in $10 \%$ formaldehyde solution for $48 \mathrm{~h}$ and routinely processed, embedded in paraffin (5-6 mm thick), and subsequent staining with hematoxylin-eosin (HE), Perls', and Schmorl's stains. Histological surface areas were measured using Image Pro Plus software 6.3. We observed that melanomacrophages around the portal vein were larger and more abundant than in the area without the bile duct. Moderate steatosis was observed in most fish, large amount of melanomacrophages and lymphocytes in the gills, liver, and spleen comparing with other studies in this species that could suggest that the immune system in these animals is constantly active. No clinical signs were observed in the fish. Studies are necessary to characterize the immune response against pathogens in elasmobranchs, especially in the Potamotrygon species.
\end{abstract}

Julieta Engrácia de Moraes

julietaengracia@gmail.com

1 Department of Veterinary Pathology, São Paulo State University (Unesp), Jaboticabal, Brazil

2 Aquaculture Center of Unesp, São Paulo State University (Unesp), Via Prof. Paulo Donato Castellane, km 05,

Jaboticabal, SP 14.884-900, Brazil
Keywords Pathology · Environment · Immunology · Parana River

\section{Introduction}

Potamotrygon is a genus of freshwater stingrays native to tropical and sub-tropical South America. These fish are one of the first taxonomic groups on the evolutionary scale to have a developed immunologic system, based on the hemogram, presence of lymphocytes, production of immunoglobulin, and major histocompatibility complex molecules (Martin 2005; Rombout et al. 2005).

In the natural environment, fish are subjected to climate changes, presence of predators, and in some cases, lack of food. Furthermore, fish from this family usually inhabit rivers surrounded by agricultural and polluted areas, as in Parana River (Guidelli et al. 2011). This basin receives high amount of washed-off nutrients and pesticides (Peltzer et al. 2008). These features may increase the susceptibility of fish to pathogens that will be reflected in the histological evaluation of the fish.

There are some reports about histological alterations in different conditions in elasmobranchs. Gill alterations were described in Isurus oxyrinchus and Prionace glauca by Wegner et al. (2010) and in Scyliorhinus canicula by Wright (1973). Oguri (1986) reported histopathological alterations in kidney of Potamotrygon sp. and Endo (1984) described the histological structure of the kidneys in Triakis scyllia, Mustelus griseus, and Raja akaei. Microscopic alterations were also described in hepatic tissue of Potamotrygon motoro (Oguri 1985), Scyliorhinus canicula (Genten et al. 2009), spleen of Chlamydoselachus anguineus (Tanaka and Goto 1991) and Raja kenojei (Tomonaga et al. 1984). 
This study aimed to describe the tissue structure of kidney, spleen, liver, and gills of wild P. motoro from the Parana River, focusing on the pathological findings.

\section{Materials and methods}

Nineteen P. motoro $(1.5 \pm 0.2 \mathrm{Kg}$ and $30.3 \pm 1.2 \mathrm{~cm}$ of disk length) were collected from the Parana River, Southern Brazil. The stingrays were euthanized by immersion in benzocaine (1:4000). Necropsy was performed, and fragments of liver, spleen, gills, and kidney were immersed in $10 \%$ formaldehyde solution for $48 \mathrm{~h}$. They were routinely processed and embedded in paraffin (Merck, Histostech) (Luna 1968). Sections of 5-6 $\mu \mathrm{m}$ thickness were prepared and stained with hematoxylin-eosin, Perls', and Schmorl's stain. Histological surface areas were measured using Image Pro Plus software 6.3 (Media Cybernetics, Silver Spring, MD, USA). $T$ test and paired $t$ test were used where appropriated.

Stingrays were captured using various fishing gear with natural baits. All institutional and national guidelines for the care and use of laboratory animals were followed: Ethical Committee of Animal Welfare of State University of São Paulo (CEUA) $n^{\circ} 18551 / 09$, and license of the Brazilian Institute of Environment and Renewable Natural Resources, IBAMA, n ${ }^{\circ}$ 19978-1/2009.

\section{Results and discussion}

The studies of freshwater stingrays are important to unveil the evolutionary history of South American fishes and to understand the physiology of this particular family. There is scarce literature about the histology of these species. Most of the studies are about their physiology (Brinn et al. 2012) and poison glands (Magalhães et al. 2008).

In this study, we observed in the liver that melanomacrophage centers around the portal vein were bigger and more abundant compared to those in areas without portal vein $(P<0.05)$ (Table 1, Fig. 1). In mammals, the degradation of the hemoglobin is performed in the liver, resulting in phagocytosis of dead blood cells by macrophages to form bile (Nelson et al. 2008). The clearance of blood particles mainly by Kupfer cells was

Table 1 Size $\left(\mu \mathrm{m}^{2}\right)$ and number of melanomacrophage centers per $480.000 \mu \mathrm{m}^{2}$, around the portal vein (PV) and in the area without PV in Potamotrygon motoro

\begin{tabular}{lllllll}
\hline & \multicolumn{3}{l}{ Around PV } & \multicolumn{4}{c}{ Area without PV } \\
\hline Size & 134.60 & \pm 63.90 & a & 106.01 & \pm 41.08 & b \\
Number & 63.20 & \pm 20.36 & a & 11.40 & \pm 9.07 & b \\
\hline
\end{tabular}

Different letters in the line indicate significant difference $(P<0.05)$

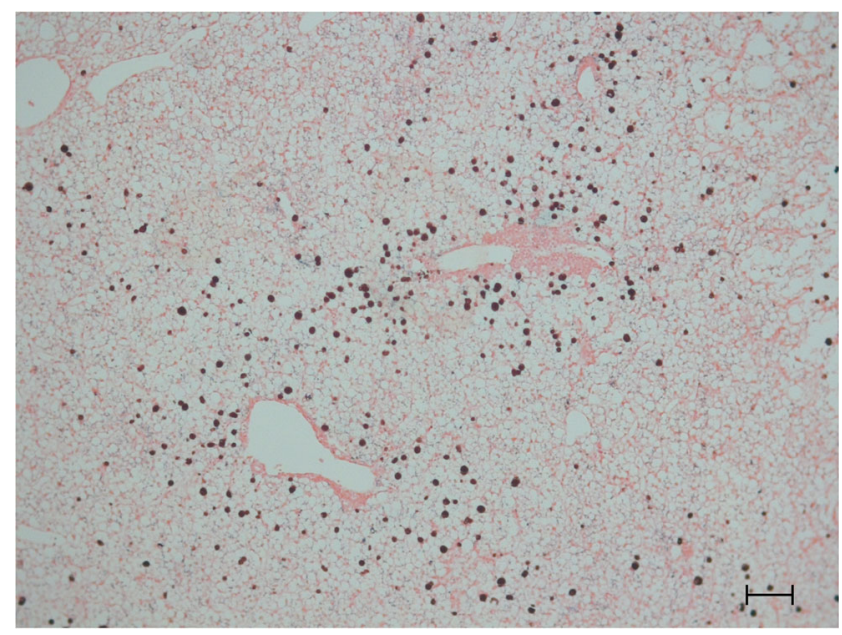

Fig. 1 Liver of Potamotrygon motoro, melanomacrophages centers around portal veins are bigger and more abundant. Perls stain. Bar: $100 \mathrm{um}$

performed in this organ (Tizard 2009). Probably, in this species of stingray, the same applies.

In this study, a high amount of intracytoplasmic vacuoles with flat and peripheral nucleus were observed in the hepatocytes of all animals, suggesting process of steatosis (Fig. 2), corroborating the findings of Oguri (1985) in this species. This finding is usually found in fish with nutritional or metabolic disorders (McGavin and Zachary 2007). The accumulation of fat in the liver may be physiological or pathological. There is great variation of the storage capacity among fish species; however, quantities of more than $45-50 \%$ in the liver of fish should be considered pathological (McClelland et al. 1995; Shimada et al. 2014), though there are no data for rays.

The liver is also responsible for the production of immunoglobulins and detoxification of xenobiotics (Baldisseroto 2002). These features make this organ the target of various contaminants, and therefore, fish are usually used as bioindicators of environmental pollution. Although xenobiotics

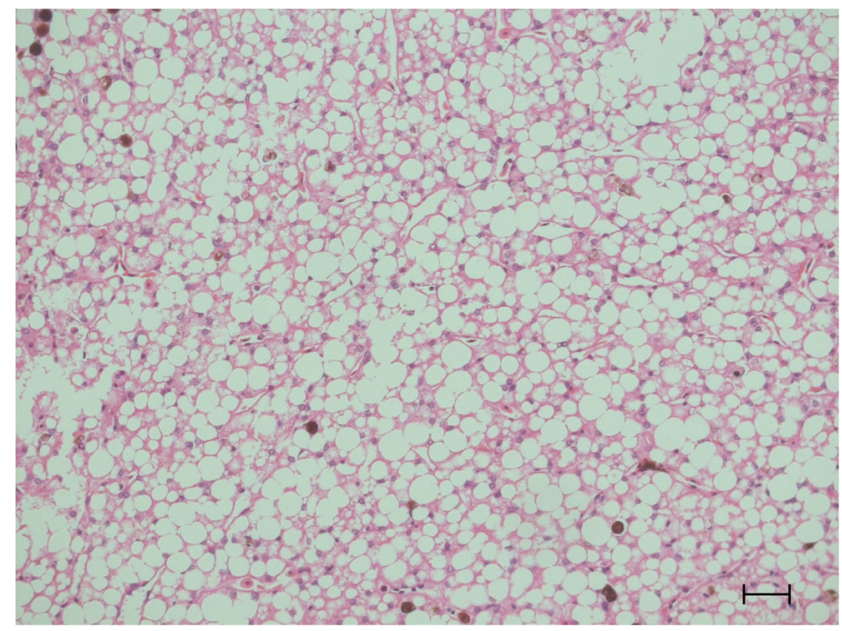

Fig. 2 Liver of Potamotrygon motoro, high amount of intracytoplasmic vacuoles with flat and peripheral nucleus. H\&E stain. Bar: 50 um 
were not surveyed in this study, steatosis is a common lesion in fish exposed to toxic agents (Teh et al. 1997; Schwaiger et al. 1997) as polyaromatic hydrocarbons, heavy metals (Di Giulio et al. 1993), and sodium perchlorate (Ahmad et al. 2009). Lesions that compromise more than $70 \%$ of the hepatic parenchyma can trigger clinical signs of a failure, such as stunted growth and predisposition to infections by opportunistic pathogens, followed by high mortality (Spisni et al. 1998; McGavin and Zachary 2007).

This species presented a classical architecture of hepatic lobules, as in mammals and teleosts, with portal triad, central veins, and a capsule of 15-20 $\mu \mathrm{m}$ layer of conjunctive tissue. Marine water elasmobranchs, like $S$. canicula, present high number of vacuolar hepatocytes and other features observed in this study (Oguri 1985). It is possible that despite the long evolution chain to reach the freshwater habitat, P. motoro still preserve the liver morphology of the marine elasmobranchs.

Brum et al. (2014) showed that silver catfish exposed to water from a polluted river (Madre) in Southern Brazil presented higher percentage of inflammatory cells in blood comparing to control group. In our study, $69.2 \%$ of the fish samples presented large number of lymphocytes in the spleen and $23.1 \%$ hyperemia comparing within the group (Fig. 3). The aspect of the spleen was similar to that described for bony fishes (Tomonaga et al. 1984, Ledic-Neto et al. 2014), including, splenic cords, sinusoid capillaries, erythrocytes, melanomacrophages, a thick capsule, and granular cells. No melanomacrophage centers were observed in this organ. Some smooth muscle fibers in the parenchyma were also observed.

The general architecture of Potamotrygon gills is similar to other elasmobranchs like I. oxyrinchus and P. glauca (Wegner et al. 2010) and S. canicula (Wright 1973). These fish present primary and secondary lamellae, skeletal muscle fibers at the base of the branchial arch, vascular sacs, pillar cells, and

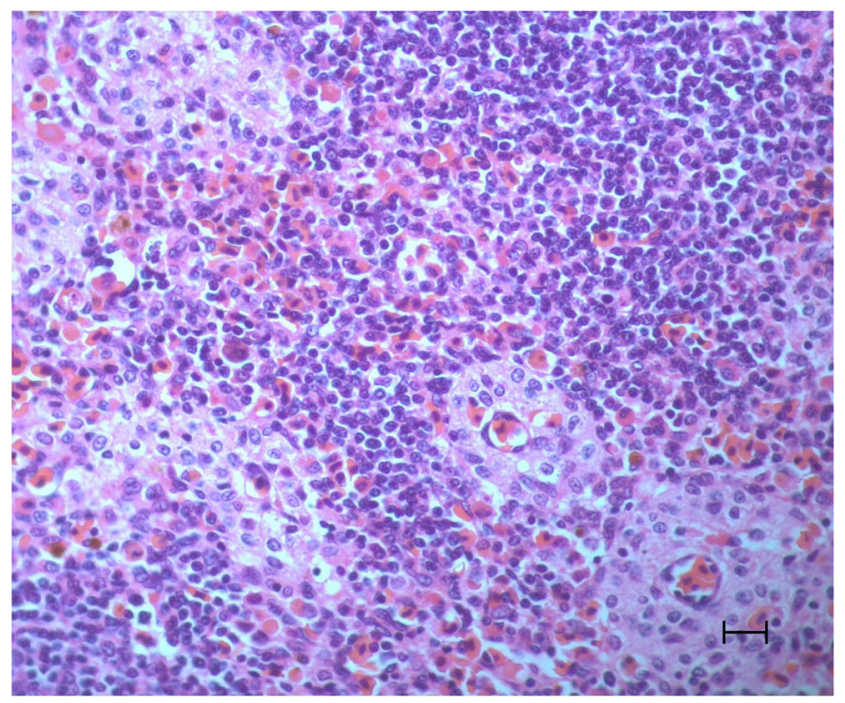

Fig. 3 Spleen of Potamotrygon motoro, high amount of lymphocytes and presence of erythrocytes in the parenquima. H\&E stain. Bar:20 um interbranchial septum. However, a large amount of isolated melanomacrophages in the corpus cavernosum of the interbranchial septum (Fig. 4) was observed in this study. It was also noticed that $14.3 \%$ of stingrays presented lamellar edema, $78.5 \%$ lamellar hypertrophy, and $78.5 \%$ lamellar hyperplasia.

Heavy metals, water acidification, and organic xenobiotics could be causes of environmental stress (Evans 1987, Brum et al. 2014). Fish from this study come from the Parana River, which is surrounded by agricultural and polluted areas (Guidelli et al. 2011). The excessive melanomacrophages found could be considered as an indicator of environmental stress (Agius and Roberts 2003). These cells have the function of storage phospholipids and iron from dead cell after phagocytosis, deposition of resistant pathogens, and processing of antigens to immune response, like dendritic cells in mammals (Agius and Roberts 2003). The high amount of melanomacrophages in the gills can indicate a center of antigen processing, similar to bronchus-associated lymphoid tissue (BALT) in mammals.

In the kidneys, the absent of justaglomerular cells corroborating the findings of Oguri (1986). As in other fish species, two types of tubules were observed: the first with cuboid epithelial cells, eosinophilic cytoplasm, marginal nucleus, and presence of microvilli protruding into the lumen, identified as proximal tubules, and the second one with cuboid epithelial cells, less eosinophilic cytoplasm, and more centralized nucleous, identified as the distal tubules. A high number of lymphocytes interspersed between the renal corpuscles in most animals were found.

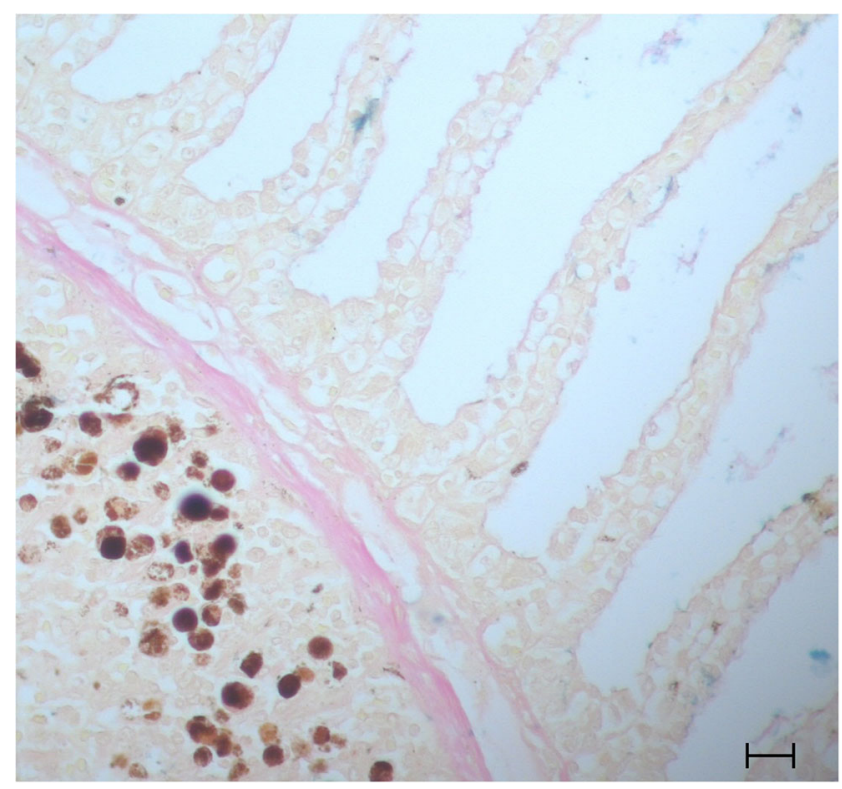

Fig. 4 Gills of Potamotrygon motoro, large amount of melanomacrophages in the corpus cavernosum of the interbranchial septum. Schmorl's stain. Bar: $20 \mathrm{um}$ 
Despite the pathological findings in the organs, the clinical aspects of the stingrays showed no signs of disease, which is unlikely due to the hostile habitat with abundant organic material, microorganism, and sediments (Neto and Uieda 2012). Probably, the immune system in these animals is constantly active. P. motoro seems to have a great defense against microorganisms in the gills, liver, and spleen, mainly due to melanomacrophages and lymphocytes. New studies are necessary to characterize the immune response against pathogens in elasmobranchs, especially in Potamotrygon genus.

\section{References}

Agius C, Roberts RJ (2003) Melano-macrophage centers and their role in fish pathology. J Fish Dis 26:499-509

Ahmad I, Özlem Ö, Sema IÜ, Burcu KT (2009) The effects of sodium perchlorate on the liver of Molly Fish (Poecilia sphenops, Cyprinidae, Teleostei). Afr J Biotechnol 8:11

Baldisseroto B (2002) Fisiologia de peixes aplicada a piscicultura. UFSM, Santa Maria, SC, Brazil

Brinn RP, Marcon JL, McComb DM, Gomes LC, Abreu JS, Baldisseroto B (2012) Stress responses of the endemic freshwater cururu stingray (Potamotrygon cf. histrix) during transportation in the Amazon region of the Rio Negro. Comp Biochem Physiol Part A 162:139-145

Brum A, Dotta G, Roumbedakis K, Gonçalves ELT, Garcia LP, Garcia P, Scussel VM, Martins ML (2014) Hematological and histopathological changes in silver catfish Rhamdia quelen (Siluriformes) exposed to clomazone herbicide in the Madre River, Santa Catarina State, Southern Brazil. J Environ Sci Health B 49:169-175

Di Giulio RT, Habig C, Gallagher EP (1993) Effects of Black Rock Harbor sediments on indices of biotransformation, oxidative stress, and DNA integrity in channel catfish. Aquat Toxicol 26:1-22

Endo M (1984) Histological and enzymatic studies on the renal tubules of some marine elasmobranchs. J Morphol 182:63-69

Evans D (1987) The fish gill: site of action and model for toxic effects of environmental pollutants. Environ Health Perspec 71:47-58

Genten F, Terwinghe E, Danguy A (2009) Atlas of fish histology. Science Publishers, Enfield, NH, USA

Guidelli G, Gomes WL, Takemoto RM, Pavanelli GC (2011) Relative condition factor and parasitism in anostomid fishes from the floodplain of the Upper Paraná River, Brazil. Vet Parasitol 177:145-151

Ledic-Neto J, Dotta G, Garcia P, Brum A, Tavares EL, Martins ML (2014) Haematology and melanomacrophage centers of Nile tilapia fed supplemented diet with própolis. Acta Sci Bio Sci 36:263-269

Luna LG (1968) Manual of the histologic staining methods of the armed forces institute of pathology, 3rd edn. McGraw Hill, New York
Magalhães MR, da Silva NJ, Ulhoa CJ (2008) A hyaluronidase from Potamotrygon motoro (freshwater stingrays) venom: isolation and characterization. Toxicon 51:1060-1067

Martin RA (2005) Conservation of freshwater and euryhaline elasmobranchs. J Mar Biol Ass UK 85:1049-1073

McClelland G, Zwingelstein G, Weber J-M, Brichon G (1995) Lipid composition of tissue and plasma in two Mediterranean fishes, the gilt-head sea bream (Chrysophyrys auratus) and the European seabass (Dicentrarchus labrax). Can J Fish Aquat Sci 52:161-170

McGavin MD, Zachary JF (2007) Pathological basis of veterinary disease. Mosby Elsevier, St. Louis, Missouri

Nelson DL, Lehninger L, Cox M (2008) Lehninger principles of biochemistry. W.H. Freeman, New York

Neto DG, Uieda VS (2012) Activity and habitat use of two species of stingrays (Myliobatiformes: Potamotrygonidae) in the upper Paraná River basin, Southeastern Brazil. Neotrop Ichthyol 10(1):81-88

Oguri M (1985) On the liver tissue of freshwater stingray and balloon fish. Bull Jpn Soc Sci Fish 51(5):717-720

Oguri M (1986) Absence of juxtaglomerular cells in the kidneys of freshwater stingrays and primitive bony fishes. Bull Jpn Soc Sci Fish 52(2):1735-1737

Peltzer PM, Lajmanovich R, Sanchez J, Cabagna M, Attademo M, Basso A (2008) Effects of agricultural pond eutrophication on survival and health status of Scinax nasicus tadpoles. Ecotoxicol Environ Saf 70: 185-197

Rombout JH, Huttenhuis HB, Picchietti S, Scapigliati G (2005) Phylogeny and ontogeny of fish leucocytes. Fish Shellfish Immunol 19:441-455

Schwaiger J, Wanke R, Adam S, Pawert M, Honnen W, Triebskorn R (1997) The use of histopathological indicators to evaluate contaminant-related stress in fish. J Aquat Ecosyst Stress \& Recovery 6:75-86

Shimada MT, Claudiano GS, Engracia Filho JR, Yunis J, Moraes FR, Moreira RG, Moraes JRE (2014) Hepatic steatosis in cage-reared young cobia, Rachycentron canadum (Linnaeus, 1766), in Brazil. J Vet Sci Med Diagn 3:2

Spisni E, Tugnoli M, Ponticelli A, Mordenti T, Tomasi V (1998) Hepatic steatosis in artificially fed marine teleosts. J Fish Dis 21:177-184

Tanaka Y, Goto M (1991) A histo-anatomical study on the spleens of a frilled shark, Chlamydoselachus anguineus. J Anat 66(1):20-26

Teh SJ, Adams SM, Hinton DE (1997) Histopathologic biomarkers in feral freshwater fish populations exposed to different types of contaminant stress. Aquat Toxicol 37(1):51-70

Tizard IR (2009) Veterinary immunology: an introduction. Saunders, St. Louis, Mo

Tomonaga S, Kobayashi K, Kajii T, Awaya K (1984) Two populations of immunoglobulin-forming cells in the skate, Raja kenojei: their distribution and characterization. Dev Comp Immunol 8:803-812

Wegner NC, Sepulveda CA, Olson KR, Hyndman KA, Graham JB (2010) Functional morphology of the gills of the shortfin mako, Isurus oxyrinchus, a lamnid shark. J Morphol 271:937-948

Wright DE (1973) The structure of the gills of the elasmobranch, Scyliorhinus canicula (L.). Z Zellforsch 144:489-509 